\title{
The Effect of a Newly Synthesized Indazole Compound, TAS-3-124, on Experimental Autoimmune Disease
}

\author{
Hirotomo Akabane, ${ }^{a}$ Naoki Miyagawa, ${ }^{a}$ Hiroaki NiI,${ }^{a}$ Yoshihiro Inami, ${ }^{a}$ Michinori Togawa, ${ }^{b}$ \\ Hiroyuki TANAKA, ${ }^{a}$ Naoki INAGAKI, ${ }^{a}$ and Hiroichi NAGAI ${ }^{*}, a$ \\ ${ }^{a}$ Department of Pharmacology, Gifu Pharmaceutical University; 5-6-1 Mitahora-higashi, Gifu 502-8585, Japan: and \\ ${ }^{b}$ Pharmacological Research Center, Taiho Pharmaceutical Company; 1-27 Misugidai, Hanno, Saitama 357-8527, Japan. \\ Received March 15, 2004; accepted May 25, 2004
}

The effects of a newly synthesized compound, 6-acetoamido-1-acetyl-1-indazole (TAS-3-124), on autoimmune diseases were studied. We used animal models of collagen-induced arthritis (CIA) in mice and experimental autoimmune encephalomyelitis (EAE) in rats to evaluate the efficacy of TAS-3-124. TAS-3-124 at doses of 100 and $300 \mathrm{mg} / \mathrm{kg}$ p.o. inhibited the development of CIA, decreasing the swelling of fore- and hind-limbs and bone destruction in knee joints. This agent also suppressed the delayed type hypersensitivity reaction (DTH) against type II collagen. These effects were confirmed by histopathological examination and measurement of the expression of mRNA of proinflammatory cytokines in the knee joint. In addition, TAS-3-124 at a dose of $300 \mathrm{mg} / \mathrm{kg} \mathrm{in-}$ hibited the development of EAE and the DTH to myelin basic protein (MBP) in rats. Moreover, TAS-3-124 inhibited the production of proinflammatory cytokines including interleukin (IL)-1 $\beta$, tumor necrosis factor (TNF)- $\alpha$ and IL-6 but not $T$ cell derived cytokines in mice. These demonstrate the efficacy of TAS-3-124 against experimental autoimmune disease, probably due to the suppression of the production of proinflammatory cytokines in the pathological lesion.

Key words TAS-3-124; tumor necrosis factor (TNF)- $\alpha$; interleukin (IL)-1 $\beta$; IL-6; collagen-induced arthritis (CIA); experimental autoimmune encephalomyelitis (EAE)

Autoimmune diseases are a type of immune-dysfunction diseases that are caused by loss of self-tolerance. The mechanisms of maintaining self-tolerance are quite complicated and still mostly obscure. The loss of self-tolerance leads to an autoimmune response and inflammatory processes, which results in tissue destruction. In the mechanisms that induce these responses, cytokines are thought to play an important role in all steps. ${ }^{1-4)}$ A representative systemic autoimmune disease is rheumatoid arthritis (RA). In this disorder, an antibody against tumor necrosis factor (TNF)- $\alpha$ decreased the symptoms of arthritis and serum levels of E-selectin and intracellular adhesion molecule-1 (ICAM-1) in RA patients. In vitro, the administration of interleukin (IL)- $1 \beta$ and interferon (IFN)- $\gamma$ or IL- $1 \beta$ and TNF- $\alpha$ increased the expression of ICAM-1 on cultured human endothelial cells from RA patients. ${ }^{6}$ During the process of tissue destruction, monocytes and $\mathrm{T}$ cells infiltrate into the pathologic tissues with the help of adhesion molecules, and activate synovial cells. Monocytes and $\mathrm{T}$ cells produce various mediators including cytokines. ${ }^{7,8)}$ IL-8 and platelet derived growth factor (PDGF) activate the proliferation of synovial cells. ${ }^{9)}$ Granulocyte and monocyte colony stimulating factor (GM-CSF), IL- $1 \beta$ and IL-6 stimulate the proliferation of fibroblasts. ${ }^{10)}$ TNF- $\alpha$, IL-6 and GM-CSF are highly expressed in the junction of cartilage and pannus of RA patients ${ }^{11)}$ and lead to cartilage destruction. ${ }^{12)}$ TNF- $\alpha$ and IL- $1 \beta$ in particular play an important role in $\mathrm{RA}^{13)}{ }^{13}$ inducing the production of collagenase, PGE2, IL-6, proteinase, peroxide and lysosomal enzymes, which promote bone destruction through activation of blood endothelial cells or synovial cells. ${ }^{14-17)}$

One of the local autoimmune diseases, multiple sclerosis (MS), also involves cytokine mechanisms during the onset and development of disease. TNF- $\alpha$ and IL- 6 exist in cerebrospinal fluid (CSF) of MS patients. ${ }^{18,19)}$ It was reported that TNF- $\alpha$ levels in CSF correspond to disease severity. ${ }^{20,21)}$
These cytokines are produced from $\mathrm{T}$ cells infiltrated into the central nervous system (CSN) through the blood brain barrier, resulting in demyelination.

Although non-steroidal anti-inflammatory drugs (NSAIDs) and steroidal anti-inflammatory drugs are often prescribed for the therapy of some autoimmune diseases, these agents have a wide range of pharmacological activity and can generate severe side effects. In this report, our goal was to find a specific therapeutic agent for the treatment autoimmune diseases through modification of cytokines. We selected a newly synthesized compound, 6-acetoamido-1-acetyl-1-indazole (TAS-3-124) because it is a cytokine modifier. In this study, we examined the effects of TAS-3-124 on type II collagen-induced arthritis (CIA) in mice and experimental autoimmune encephalomyelitis (EAE) in rats. We also examined the effects of TAS-3-124 on cytokine production in vivo by using a C. parvum-LPS model of cytokine induction and in vitro by using Th1 or Th2 cell lines.

\section{MATERIALS AND METHODS}

Animals We purchased 8 week old male DBA/1J mice, 8 week old female DA rats and 7 week old female ddY mice from Japan SLC (Shizuoka, Japan). Animals were housed in an air-conditioned room at $24^{\circ} \mathrm{C}$, fed a standard laboratory diet, and given water ad libitum. All experiments were carried out following guidelines for the care and use of experimental animals published by the Japanese Association for Laboratory Animal Science in 1987.

Drugs TAS-3-124 (Fig. 1) was donated by Taiho pharmaceutical Co. Ltd. (Tokyo, Japan). For in vivo studies, TAS3-124 and prednisolone acetate (Pred; Shionogi \& Co. Ltd., Osaka, Japan, a positive control) were suspended in $0.5 \%$ sodium carboxymethyl cellulose solution (CMC-Na). Matched controls received vehicle only. These drugs were 


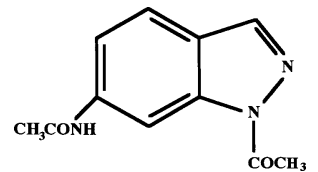

Fig. 1. Chemical Structure of 6-Acetoamide-1-acetyl-1H-indazole (TAS3-124)

administered $6 \mathrm{~d}$ a week orally for 9 weeks. TAS-3-124 did not cause a significant decrease of body weight after administration. For in vitro studies, TAS-3-124 was dissolved in dimethyl sulfoxide (DMSO) and diluted to make different concentrations. The solutions were then diluted in the culture medium at $0.1 \%$ DMSO final concentration. Control cultures were exposed to the medium containing $0.1 \%$ DMSO.

CIA in Mice CIA was induced in DBA/ $1 \mathrm{~J}$ mice as described previously. ${ }^{22}$ Mice were injected intradermally at the dorsal skin with $200 \mu \mathrm{g}$ of bovine type II collagen (CII; Cosmo Bio, Tokyo, Japan) in complete Freund's adjuvant (CFA; Sigma, St Louis, MO, U.S.A.). Three weeks after the initial injection, the booster immunization with $200 \mu \mathrm{g}$ of bovine CII emulsified in CFA was injected intradermally at the base of the tail.

Clinical symptoms of arthritis in the extremities were monitored by the same observer at weeks 3, 4, 5, 6, 7 and 9 after the initial immunization. The severity of arthritis in the metacarpophalangeal wrist, metatarsophalangeal wrist, and ankle joints was scored using an established macroscopic scoring system: $0=$ normal, $1=$ swelling and erythema of 1 to 2 digits, $2=$ swelling and erythema of $3-5$ digits, $3=$ mild swelling and erythema of the limb, $4=$ gross swelling and erythema of limb, $5=$ gross swelling and erythema of the limb with joint rigidity. The arthritis index for each mouse was calculated by adding the individual scores of each of the four extremities.

In addition to the arthritis index, the paw volume was measured with a plethysmometer (TK-101, Unicom, Chiba, Japan). At the end of the experiment (week 8), bone change was radiographically evaluated using a softex X-ray apparatus (PK-5, Shimadzu Rika Instruments Co., Kyoto, Japan). Bone changes for knee and foot joints were graded on a scale of $0-3$ : $0=$ negative; $1=$ subtle erosions; $2=$ mild erosions; $3=$ severe erosions. The values from the softex index were calculated by adding individual values of the four joints of the hind limbs (Total value ranged between 0 and 12).

At the end of the experiments, histopathological studies of knee joints were carried out. Animals were sacrificed under anesthesia and both hind limbs of mice were amputated and immersed in 10\% formalin. The knee joints were decalcified, embedded in paraffin, sectioned and stained with hematoxylin and eosin. A histopathological analysis was carried out to evaluate degeneration of cartilage and formation of pannus. Changes observed in the lesions were classified into four grades: $0=$ negative; $1=$ slight change; $2=$ mild change; $3=$ marked change (Total score ranged from 0 to 6 ).

DTH Reaction to CII in CIA At the 8th week, cell-mediated immune responses to CII were assessed by measuring delayed-type hypersensitivity (DTH) reactions as follows. An aliquot $(10 \mu \mathrm{l})$ of $\mathrm{CII}$ in phosphate-buffered saline, $\mathrm{pH} 7.0$, was injected intradermally into each ear, and the ear thickness was measured by a dial thickness gauge (R2-1A, Ozaki
MFG Co. Ltd., Tokyo, Japan) $24 \mathrm{~h}$ after the injection of CII. The antigen-specific DTH response was estimated by measuring the increase in ear thickness at $24 \mathrm{~h}$.

mRNA Preparation and cDNA Synthesis RNA was extracted using ISOGEN $^{\circledR}$ (Nippon Gene, Toyama, Japan) according to the manufacturer's instruction and RNase-free plastic and water were used throughout the assay. Briefly, at 0,3 and 5 weeks, knee joints and lymph nodes from two control mice or treated mice were quickly frozen with liquid $\mathrm{N}_{2}$. They were then homogenized with a Polytrone after immersion into $5 \mathrm{ml}$ (knee joint) or $3 \mathrm{ml}$ (lymph node) ISOGEN ${ }^{\circledR}$ (Nippon Gene, Toyama, Japan). Thereafter, $0.2 \mathrm{ml}$ of chloroform was added to each $1 \mathrm{ml}$ sample, and the mixture was shaken vigorously and incubated for $3 \mathrm{~min}$ at room temperature. After centrifugation at $12000 \times \boldsymbol{g}$ for $15 \mathrm{~min}$ at $4{ }^{\circ} \mathrm{C}$, $0.5 \mathrm{ml}$ of isopropanol was added to the aqueous phase. The RNA precipitates were obtained after centrifugation at $12000 \times \boldsymbol{g}$ for $10 \mathrm{~min}$ at $4{ }^{\circ} \mathrm{C}$ washed once with $1 \mathrm{ml}$ of $75 \%$ ethanol and suspended in $50 \mu$ l of water. The amount of total RNA in each sample was measured spectrophotometrically at $260 \mathrm{~nm}$ with Gene Quant (Pharmacia Biotech, Cambridge, U.K.). To ascertain whether the RNA was undegraded and that the concentration had been correctly determined, RNA $(1 \mu \mathrm{g})$ was electrophoresed on $1.5 \%$ agarose gel containing ethidium bromide. The gel was photographed and each individual lane was examined for the presence of the $18 \mathrm{~S}$ and $28 \mathrm{~S}$ ribosomal bands.

The RT-reaction used here was a modification of the method from the 3' RARE kit of Gibco BRL. Reverse transcription of RNA was carried out with a Trio-Thermoblock (Biometra, Göttingen, Germany). An aliquot, $12 \mu \mathrm{l}$, of a reaction mixture containing $1 \mu \mathrm{g}$ RNA and random primer was heated for $10 \mathrm{~min}$ at $70^{\circ} \mathrm{C}$ in order to denature the RNA, and then chilled on ice immediately. Next, $4 \mu \mathrm{l}$ of 5 -fold firststrand buffer, $1 \mu \mathrm{l}$ of $10 \mathrm{mmol} / 1 \mathrm{dNTP}$, and $2 \mu \mathrm{l}$ of $0.1 \mathrm{~mol} / 1$ dithiothreitol were added to the mixture and it was stored for $5 \mathrm{~min}$ at $25^{\circ} \mathrm{C}$ in order to anneal RNA strains with primer. The SuperScript ${ }^{\mathrm{TM}}$ II RNase H-reverse transcriptase was added, and the contents were mixed and incubated for $10 \mathrm{~min}$ at $25^{\circ} \mathrm{C}$, and then for $50 \mathrm{~min}$ at $42^{\circ} \mathrm{C}$. The reaction was next heated for $15 \mathrm{~min}$ at $70^{\circ} \mathrm{C}$, and then quickly chilled on ice.

PCR for Cytokine Expression in Knee Joint and Lymph Node PCR was performed with Trio-Thermoblock. To the RT mixture $(1 \mu \mathrm{l})$ the following components were added: $5 \mu \mathrm{l}$ of PCR buffer, $4 \mu \mathrm{l}$ of deoxynucleotide triphosphate mixture, $1 \mu \mathrm{l}$ of sense primer, $1 \mu \mathrm{l}$ of antisense primer, $37.75 \mu \mathrm{l}$ of RNase free water and $0.25 \mu \mathrm{l}$ Taq Polymerase $(5 \mathrm{U} / \mu \mathrm{l})$. The sequences of primers were as follows: TNF- $\alpha$ : 5'-ATGAGCACAGAAAGCATGATC-3' and 5'-TACAGGCTTGTCACTCGAATT-3'; IL-1 $\beta$ : 5'-CAGGATGAGGACATGAGCACC-3' and 5'-CTCTGCAGACTCAAACTCCAC-3'; IFN- $\gamma$ : 5' -TACTGCCACGGCACAGTCAT TGAA-3' and 5'-GCAGCGACTCCTTTTCCGCTTCCT-3'; $\beta$-actin: 5'-GTGGGCCGCTAGGCACCA-3' and 5'-CGGTTGGCCTTAGGGTTCAGGGGGG-3'.

After an initial incubation at $94{ }^{\circ} \mathrm{C}$ for $5 \mathrm{~min}$ and $62^{\circ} \mathrm{C}$ for $5 \mathrm{~min}$, temperature cycling was started with each cycle as follows; $94^{\circ} \mathrm{C}$ for $1.5 \mathrm{~min}$ (denaturation), $62^{\circ} \mathrm{C}$ for $1.5 \mathrm{~min}$ (annealing of primers) and $72^{\circ} \mathrm{C}$ for $1.5 \mathrm{~min}$ (elongation). We used 30 cycles for IL- $1 \beta$ and $\beta$-actin and 35 cycles for TNF- $\alpha$ and IFN- $\gamma$. As a control, an equal amount of RNA 
was added to each PCR reaction, and primers for $\beta$-actin were used to amplify the cDNA.

An aliquot, $10 \mu \mathrm{l}$, of the final reaction mixture was run on a $2.5 \%$ agarose gel containing ethidium bromide at $50 \mathrm{~V}$ for 30 - 60 min. Each band of PCR products detected with UV was exposed to Polaroid Type T667 Film (U.K.). The relative amounts of PCR products were quantified using the NIH image system.

EAE in Rats EAE was induced in DA rats as described previously. ${ }^{23)}$ Briefly, rats were injected subcutaneously (s.c.) in both hind footpads with bovine myelin basic protein (MBP; Sigma, St Louis, MO, U.S.A.) emulsified in CFA (Sigma). To evaluate the efficacy of TAS-3-124, the drug was administered orally every day from day 0 to day 11 after immunization with MBP. The clinical symptoms of EAE were evaluated every day for $25 \mathrm{~d}$ after the immunization by the same observer using a macroscopic scoring system as follows: $0=$ normal; $1=$ flaccid tail; $2=$ partial paralysis of hind feet; $3=$ complete paralysis of hind feet; $4=$ paralysis of the fore feet.

To confirm the symptom, histopathological studies of the spinal cord were carried out. On day 13, when the maximum clinical symptoms were exhibited, rats were sacrificed under anesthesia, and the spinal cord was stained with hematoxylin and eosin. Then a histopathological analysis was done using by light microscopy.

DTH Reaction to MBP in EAE To estimate the cellular immune response, the DTH reaction to MBP was measured at day 11 and 22 after immunization. An aliquot, $50 \mu \mathrm{l}$, of $0.4 \mathrm{mg} / \mathrm{ml} \mathrm{MBP}$ solution in PBS was injected intradermally into the skin of the left ear and an equal volume of PBS was injected into the skin of the right ear. After $48 \mathrm{~h}$ the thickness of each ear was measured with a dial thickness gauge (R21A, Ozaki MFG Co. Ltd.). The DTH reaction was determined as the thickness at $48 \mathrm{~h}$ after the injection minus that before the injection.

In Vivo Cytokine Production Corynebacterium parvum (C. parvum; $0.5 \mathrm{mg}$, Funakoshi Co. Tokyo, Japan) suspended in physiological saline was injected intravenously (i.v.) into ddY mice. Seven days later, lipopolysaccharide (LPS; Sigma, St. Louis, MO, U.S.A.) solution at a dose of $10 \mu \mathrm{g} / \mathrm{kg}$ was injected i.v.. Since the production of cytokines reached the maximum $2 \mathrm{~h}$ after LPS injection in preliminary experiments, sera were collected $2 \mathrm{~h}$ after the injection of LPS. The amounts of TNF- $\alpha$ IL- $1 \beta$ and IL-6 were measured using ELISA kits (Endogen Inc., Cambridge, MA, U.S.A.) and calculated using a standard curve.

IFN- $\gamma$ or IL-4 Production by E10 or D10 Cells The mouse Th1 cell line 1E10.H2 (E10), established from the $\mathrm{C} 3 \mathrm{H}$ mouse $(\mathrm{H}-2 \mathrm{k})$ which is specific for keyhole limpet hemocyanin (KLH), was a gift of Prof. Hitoshi Omori (University of Okayama, Japan). E10 cells were maintained in 10\% fetal calf serum (FCS) in RPMI 1640 medium (Gibco BRL Co, Gaithersburg, MD, U.S.A.) and Dulbecco's modified Eagle medium (DMEM, Gibco BRL, volume of RPMI 1640 and DMEM: 1 to 1 ) with $2 \mathrm{mmol} / \mathrm{l} \mathrm{L}$-glutamine, $1 \mathrm{mmol} / \mathrm{l}$ pyruvate, $50 \mu \mathrm{mol} / 1$ 2-mercaptoethanol (2-ME), $100 \mathrm{U} / \mathrm{ml}$ penicillin G-100 $\mu \mathrm{g} / \mathrm{ml}$ streptomycin sulfate. The mouse Th2 cell line D10.G4.1 (D10), derived from AKR/J mouse (H-2k) and specific for conalbumin, was purchased from American Type Culture Collection (Rockville, MD, U.S.A.). D10 cells were maintained in Click's medium (Gibco BRL) with $10 \%$ FCS, $2 \mathrm{mmol} / 1 \mathrm{~L}$-glutamine, $50 \mu \mathrm{mol} / 12-\mathrm{ME}, 100 \mathrm{U} / \mathrm{ml}$ penicillin G-100 $\mu \mathrm{g} / \mathrm{ml}$ streptomycin sulfate. Every $7 \mathrm{~d}$, cells were stimulated with $50 \mu \mathrm{g} / \mathrm{ml} \mathrm{KLH} \mathrm{(E10;} \mathrm{Sigma)} \mathrm{or} 50 \mu \mathrm{g} / \mathrm{ml}$ of conalbumin (D10) in the presence of mitomycin C-treated $\mathrm{C} 3 \mathrm{H} / \mathrm{HeN}$ (E10), or AKR/J (D10) splenocytes (as APCs) which were maintained in $10 \%$ rat growth factor. This growth factor is the supernatant from rat splenocytes that had been stimulated with concanavalin A (ConA) for $48 \mathrm{~h}$ and which contained $20 \mathrm{mg} / \mathrm{ml} \alpha$-methyl-D-mannoside.

Each cell clone $\left(7.5 \times 10^{4}\right.$ cells per well) was incubated with ConA $(5 \mu \mathrm{g} / \mathrm{ml}$ for E10 and $10 \mu \mathrm{g} / \mathrm{ml}$ for D10) in the presence or absence of various concentrations of TAS-3-124 and CsA. The cultures were maintained in a 48-well flat-bottomed Multiwell ${ }^{\mathrm{TM}}$ Tissue Culture Plate (Falcon, Becton Dickinson Co., Franklin Lakes, NJ, U.S.A.) for $24 \mathrm{~h}$ (E10) or $48 \mathrm{~h}$ (D10) at $37^{\circ} \mathrm{C}$ in an atmosphere of $5 \% \mathrm{CO}_{2}$. The amount of IFN- $\gamma$ and IL-4 was measured by ELISA kit (Endogen) using the supernatants which were collected in experiments on each cell clone at the indicated time. Results were expressed as the arithmetic means \pm S.E.M. from quadruplicate cultures.

Statistical Analyses Dunnett's multi-comparison method was used for statistical analysis of control group versus drugtreated groups. Mann-Whitney method was used only for the arthritis index and the softex index in CIA and for the clinical score in EAE. Results are expressed as the mean or the mean \pm S.E.M. $p$ values less than 0.05 were considered to be statistically significant.

\section{RESULTS}

Effect of TAS-3-124 on CIA in Mice To assess the efficacy on rheumatoid arthritis, the effect of TAS-3-124 on CIA in DBA/1J mice was studied. Three weeks after the primary immunization, slight redness and edema of the foot pad were observed in control mice. After the second immunization with bovine CII, severe symptoms of polyarthritis were observed in control group, whereas mice treated with TAS-3124 at doses more than $100 \mathrm{mg} / \mathrm{kg}$ did not show severe symptoms of arthritis (Fig. 2).

In histopathological studies of joints, a chronic proliferative synovitis, degeneration and erosion of cartilage and the formation of pannus were observed in the control group. TAS-3-124 inhibited bone changes in radiographical and histopathological studies (Fig. 3, Table 1). TAS-3-124 also decreased the DTH reaction to CII when measured at 9 weeks after the primary immunization (Table 2).

To exclude the suppressive mechanism of arthritis, the effects of TAS-3-124 on cytokine mRNA expression in knee joints and lymph nodes in CIA mice were investigated. Following the development of arthritis, TNF- $\alpha$ and IL- $1 \beta$ mRNA expression levels in knee joints and the IFN- $\gamma$ mRNA expression level in lymph nodes were gradually increased at 3 and 5 weeks after primary immunization. TAS-3-124 and Prednisolone inhibited the increase in cytokine mRNA expression (Table 3).

Effect of TAS-3-124 on EAE in Rats The effect of TAS-3-124 on EAE, an animal model for multiple sclerosis, was also studied. At $11 \mathrm{~d}$ after immunization, tail or hindlimb paralysis emerged in control rats. The average of the 
EAE symptoms reached a maximum at day 12 , but had completely remitted at day 18 . TAS-3-124 at doses of 30 and 100 $\mathrm{mg} / \mathrm{kg}$ had little effect on these EAE symptoms, but TAS-3124 at a dose of $300 \mathrm{mg} / \mathrm{kg}$ completely suppressed them.
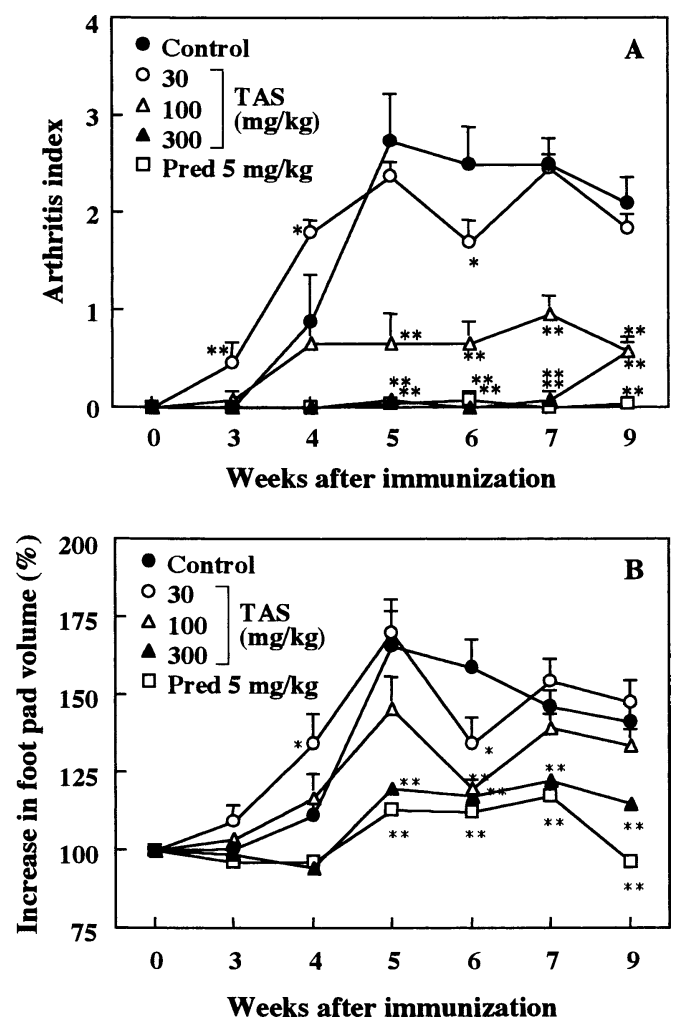

Fig. 2. Effects of TAS-3-124 (TAS) and Prednisolone Acetate (Pred) on a Collagen-Induced Arthritis Index in DBA/1J Mice

(A) Arthritis Index, (B) foot pad volume. TAS-3-124 was administrated p.o. 6 times per week. Each value represents mean \pm S.E.M. of 6 mice. $* p<0.05$, $* * p<0.01$, significantly different from the control response (A; Mann-Whitney test). (B; Dunnett's multiple range test)

Table 1. Effect of TAS-3-124 and Prednisolone on Histopathological Score and Softex Index in the Knee Joint from Collagen-Induced Arthritis Mice

\begin{tabular}{lccccc}
\hline \hline Group & $\begin{array}{c}\text { Dose } \\
(\mathrm{mg} / \mathrm{kg})\end{array}$ & $n$ & $\begin{array}{c}\text { Synovial } \\
\text { proliferation }\end{array}$ & $\begin{array}{c}\text { Formation } \\
\text { of pannus }\end{array}$ & $\begin{array}{c}\text { Softex } \\
\text { index }\end{array}$ \\
\hline Control & & 6 & $2.3 \pm 0.4$ & $2.3 \pm 0.6$ & $6.0 \pm 0.4$ \\
TAS & 30 & 6 & $2.3 \pm 0.4$ & $2.1 \pm 0.5$ & $5.3 \pm 0.8$ \\
& 100 & 6 & $1.6 \pm 0.5$ & $1.4 \pm 0.6$ & $3.3 \pm 1.0^{*}$ \\
& 300 & 6 & $0.0 * *$ & $0.0^{* *}$ & $0.2 \pm 0.2^{* *}$ \\
Pred & 5 & 6 & $0.0 * *$ & $0.0^{* *}$ & $0.5 \pm 0.3 * *$ \\
\hline
\end{tabular}

Each index was measured 9 weeks after the primary immunization. Histopathological change was graded on scale of $0-3 . * p<0.05, * * p<0.01$.
Prednisolone also strongly suppressed the development of disease (Fig. 4).

As for cell-mediated immune responses against MBP, we assessed the DTH reaction on day 11 (during the drug treatment) and day 22 (after stopping the treatment). TAS-3-124 at doses of 30 and $100 \mathrm{mg} / \mathrm{kg}$ significantly suppressed ear swelling on day 11 but did not affect it on day 22 . TAS-3-124

Table 2. Effect of TAS-3-124 and Prednisolone on Delayed Type Hypersensitivity Reaction in Collagen-Induced Arthritis Mice

\begin{tabular}{lrcc}
\hline \hline Group & $\begin{array}{c}\text { Dose } \\
(\mathrm{mg} / \mathrm{kg})\end{array}$ & $n$ & $\begin{array}{c}\text { Swelling } \\
(\mu \mathrm{m})\end{array}$ \\
\hline Control & & 6 & $290.4 \pm 19.6$ \\
TAS & 30 & 6 & $260.0 \pm 15.0$ \\
& 100 & 6 & $244.8 \pm 17.9$ \\
Pred & 300 & 6 & $196.3 \pm 41.6^{*}$ \\
& 5 & 6 & $160.8 \pm 19.4^{* *}$
\end{tabular}

Each value represents the mean of 6 animals. Ear swelling was measured $24 \mathrm{~h}$ after the challenge at 9 week. $* p<0.05, * * p<0.01$.

Table 3. Effect of TAS-3-124 and Prednisolone on Cytokine mRNA Expression in the Knee Joint of Collagen-Induced Arthritis Mice

\begin{tabular}{llrrr}
\hline \hline & & TNF- $\alpha$ & IL-1 $\beta$ & INF- $\gamma$ \\
\hline Normal & & 1.8 & 0.0 & 0.0 \\
Control & $(5 \mathrm{w})$ & 11.5 & 10.0 & 11.8 \\
TAS & $300 \mathrm{mg} / \mathrm{kg}$ & 7.4 & 6.4 & 11.5 \\
Pred & $5 \mathrm{mg} / \mathrm{kg}$ & 2.0 & 5.7 & 6.1 \\
\hline
\end{tabular}

INF- $\gamma$ was measured in spleen. Each value represents the standardized value by $\beta$ actin. Each value represents the mean of duplicate experiments.

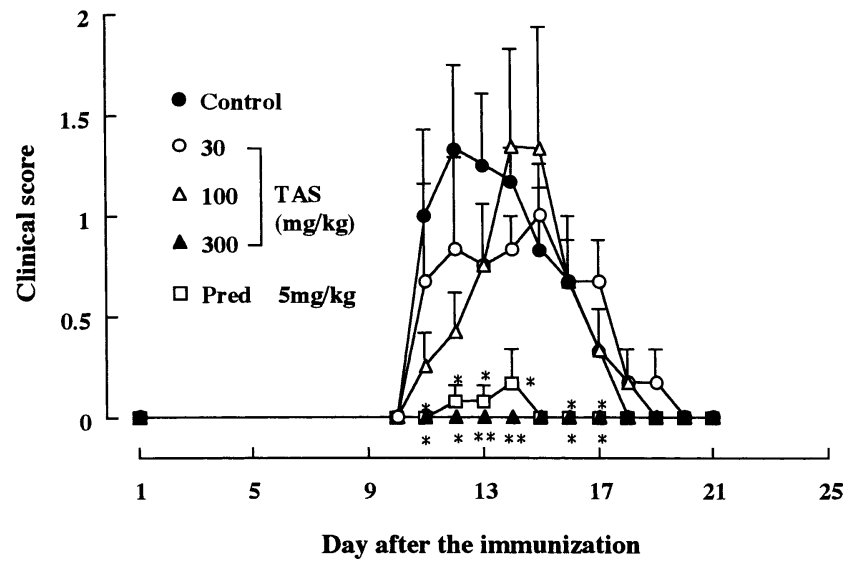

Fig. 4. Effects of TAS-3-124 (TAS) and Prednisolone Acetate (Pred) on the Clinical Course of EAE in DA Rats

The rats were immunized with $100 \mu \mathrm{g}$ of bovine MBP in CFA emulsion, and the drugs were administered orally, daily, from day 1 to day 12 post immunization. Each value represents the mean \pm S.E.M. of 6 rats per group. $* p<0.05$, $* * p<0.01$, significantly different from the control response (Mann-Whitney test).
A: Control

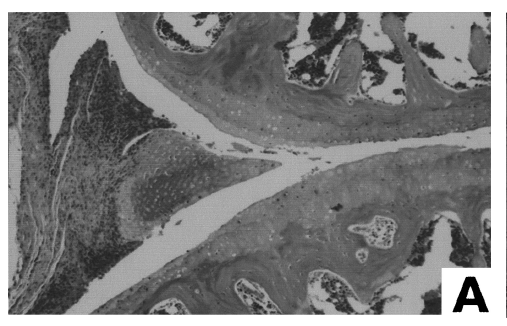

B: Prednisolone $5 \mathrm{mg} / \mathrm{kg}$

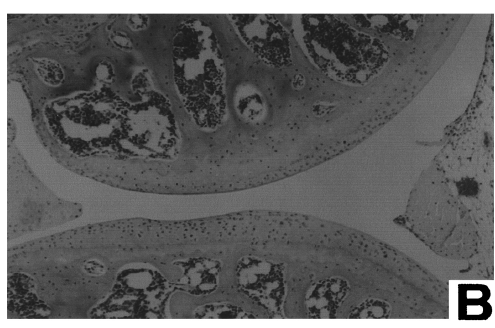

C: TAS-3-124 300 mg/kg

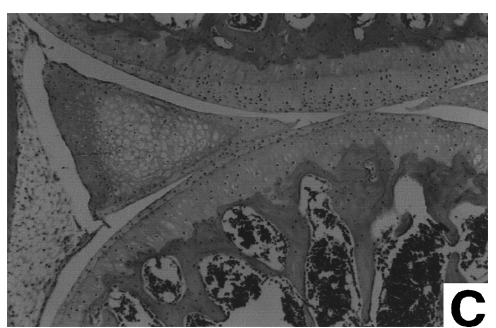

Fig. 3. Histological Study of Knee Joint in CIA-Induced DBA/1J Mice at 9 Weeks 
at a dose of $300 \mathrm{mg} / \mathrm{kg}$ substantially suppressed the DTH reaction on both day 11 and 22. Prednisolone also significantly suppressed the increase of ear thickness on both day 11 and 22 (Table 4).

In histopathological studies of the spinal cord, significant cell infiltrations were observed around the medulla and meninges in control rats on day 12 . TAS-3-124 inhibited this cell infiltration (Fig. 5).

Effect of TAS-3-124 on Cytokine Production in Vivo We used an in vivo model to investigate the ability of TAS-3124 to suppress cytokine production. After the injection of LPS and $C$. parvum into ddY mice, the amount of TNF- $\alpha$, IL- $1 \beta$ and IL- 6 in sera increased significantly in the control group. TAS-3-124 at a dose of $300 \mathrm{mg} / \mathrm{kg}$ inhibited the production of TNF- $\alpha$ and IL-1 $\beta$. TAS-3-124 significantly suppressed the production of IL-6 at doses of more than 100 $\mathrm{mg} / \mathrm{kg}$ (Table 5).

Effects of TAS-3-124 on IFN- $\gamma$ or IL-4 Production by T Cells To measure the effects of TAS-3-124 on cytokine production by $\mathrm{T}$ cells, Th1 and Th2 cell clones were stimulated with Con A. TAS-3-124 did not affect the production of IFN- $\gamma$ by Th1 cell clones or IL- 4 production by Th2 cell

Table 4. Effect of TAS-3-124 and Prednisolone on Delayed Type Hypersensitivity Reaction in Myelin Basic Protein-Induced Experimental Autoimmune Encepharpmuelitis Rats

\begin{tabular}{|c|c|c|c|c|}
\hline \multirow{2}{*}{ Group } & \multirow{2}{*}{$\begin{array}{c}\text { Dose } \\
(\mathrm{mg} / \mathrm{kg})\end{array}$} & \multirow{2}{*}{$n$} & \multicolumn{2}{|c|}{ Swelling $(\mu \mathrm{m})$} \\
\hline & & & Day 11 & Day 22 \\
\hline Control & & 6 & $776.7 \pm 67.7$ & $716.3 \pm 101.0$ \\
\hline \multirow[t]{3}{*}{ TAS } & 30 & 6 & $576.7 \pm 14.0^{*}$ & $791.3 \pm 110.3$ \\
\hline & 100 & 6 & $545.8 \pm 25.7 * *$ & $751.3 \pm 92.7$ \\
\hline & 300 & 6 & $225.8 \pm 44.8^{* *}$ & $242.9 \pm 69.9 * *$ \\
\hline Pred & 5 & 6 & $343.3 \pm 55.2 * *$ & $373.8 \pm 52.1^{*}$ \\
\hline
\end{tabular}

Each value represents the mean of 6 animals. Ear swelling was measured $48 \mathrm{~h}$ after the challenge at day 11 and $22 \mathrm{~d} . * p<0.05, * * p<0.01$.

Table 5. Effect of TAS-3-124 and Prednisolone on LPS-Induced Cytokine Production in Mice Pretreated with C. parvum

\begin{tabular}{|c|c|c|c|c|c|}
\hline Group & $\begin{array}{c}\text { Dose } \\
(\mathrm{mg} / \mathrm{kg})\end{array}$ & $n$ & $\begin{array}{l}\text { TNF- } \alpha \\
(\mathrm{ng} / \mathrm{ml})\end{array}$ & $\begin{array}{c}\mathrm{IL}-1 \beta \\
(\mathrm{ng} / \mathrm{ml})\end{array}$ & $\begin{array}{c}\text { IL-6 } \\
(\mathrm{ng} / \mathrm{ml})\end{array}$ \\
\hline Control & & 8 & $246.0 \pm 55.8$ & $3.4 \pm 0.9$ & $98.4 \pm 17.1$ \\
\hline \multirow[t]{3}{*}{ TAS } & 30 & 8 & $143.8 \pm 43.3$ & $2.2 \pm 0.7$ & $69.7 \pm 15.3$ \\
\hline & 100 & 8 & $199.9 \pm 137.9$ & $2.5 \pm 1.1$ & $41.0 \pm 21.0 *$ \\
\hline & 300 & 8 & $13.6 \pm 6.5^{* *}$ & $0.3 \pm 0.2 * *$ & $9.1 \pm 9.1 * *$ \\
\hline Pred & 5 & 8 & $0.0 * *$ & $0.4 \pm 0.2 * *$ & $0.0 * *$ \\
\hline
\end{tabular}

Each cytokine was measured in the serum obtained $2 \mathrm{~h}$ after the injection of LPS Drug was administered per orally once a day for $8 \mathrm{~d}$ before injection of LPS. $* p<0.05$, $* * p<0.01$ clones (data not shown).

\section{DISCUSSION}

In this study, we demonstrated the efficacy of a newly synthesized indazole compound, TAS-3-124, in an experimental arthritis model in mice and a multiple sclerosis model in rats. In addition, the present data suggest that the pharmacological actions of TAS-3-124 are closely related to the inhibition of proinflammatory cytokine production and cell-mediated immune responses.

The increasing understanding of the pathophysiology of a number of human autoimmune diseases and the realization of cytokine's role in these disorders has provided us with a wide array of new targets for therapeutic interventions. ${ }^{24-26)}$ Targeting cytokines by means of inhibitory drugs may thus offer a valid therapeutic approach in autoimmune disease. Novel therapeutic agents such as monoclonal antibodies, cytokine receptor-human immunoglobulin constructs or small molecules have been tested in rheumatoid arthritis with some success. $^{1-4,24-26)}$ In particular, clinical trials testing antiTNF- $\alpha$ agents either alone or in combination with methotrexate have convincingly demonstrated the feasibility and efficacy of these novel approaches to the therapy of rheumatoid arthritis.

The present data demonstrate the inhibitory activity of TAS-3-124 on the production of proinflammatory cytokines. In the experiment employing $C$. parvum and LPS, the production of TNF- $\alpha$, IL- $1 \beta$ and IL- 6 was inhibited. But the production of Th1 and Th2 cytokines were not affected. These data thus indicate that TAS-3-124 selectively inhibits the production of proinflammatory cytokines rather than $\mathrm{T}$ cell cytokines. In addition, the TAS-3-124 doses required to interfere with the production of cytokines are somewhat higher than the doses required to inhibit the development of arthritis. This may be due to a synergistic effect between the inhibitory action of TAS-3-124 on the cytokine production and another mechanism.

In addition, TAS-3-124 interfered with the delayed type hypersensitivity reaction in both models. This suggests an inhibitory mechanism of TAS-3-124 on cell-mediated immune responses. However, the doses required to inhibit the DTH were not matched to the doses required to inhibit the development of experimental diseases. These findings suggest a participation of the anti-DTH mechanism of TAS-3-124 in the anti-disease mechanism of TAS-3-124, but the degree of involvement may dose not appear to be high.

Regarding the biological activity of indazole compounds, several pharmacological actions have been reported so
A: Control

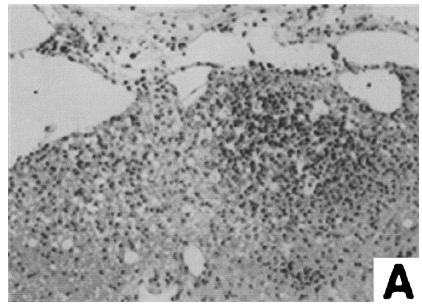

B: Prednisolone $5 \mathrm{mg} / \mathrm{kg}$

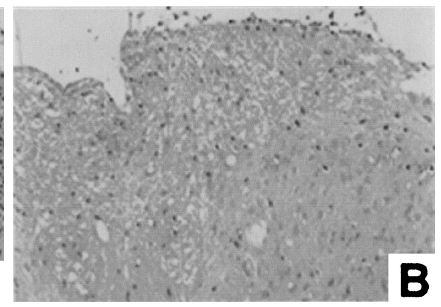

\section{C: TAS-3-124 $300 \mathrm{mg} / \mathrm{kg}$}

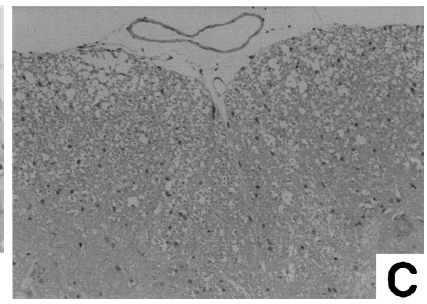

Fig. 5. Histological Study of Spinal Cord in EAE-Induced DA Rats 
far. $^{27-31)}$ Some compounds are reported to have an anti-inflammatory activity mainly due to interfering with inflammatory enzymes. Therefore, further experiments concerning the effects of TAS-3-124 on the activity of inflammatory enzymes will be necessary in the future.

Concerning the effect of TAS-3-124 on humoral immune responses, TAS-3-124 did not affect the production of pathological antibody in either model. This is consistent with the effect of TAS-3-124 on IFN- $\gamma$ and IL-4 production by each cell line. TAS-3-124 suppressed IFN- $\gamma$ production by the Th1 cell line, 1E10.H2 cells, only at a dose of $10^{-4} \mathrm{M}$. This dose is too high to be considered operative in the pharmacological action of TAS-3-124 in vivo.

In conclusion, we investigated the possibility of TAS-3124 as a therapeutic agent for autoimmune diseases, especially for RA or MS. The present data indicate that TAS-3124 can substantially suppress the clinical scores of mouse CIA and rat EAE. These data suggest the high likelihood that the clinical application of TAS-3-124 can be used as a remedy for at least some autoimmune diseases, although the detailed therapeutic mechanisms of TAS-3-124 remain obscure.

\section{REFERENCES}

1) Feldmann M., Miotla J., Paleolog E., Williams R., Malfait A. M., Taylor P., Brennan F. M., Maini R. N., Ann. Rheum. Dis., 59 (Suppl. 1), i119-122 (2000).

2) Haraoui B., Strand V., Keystone E., Curr. Pharm. Biotechnol., 1, 217-233 (2000).

3) Pascual M., Nieto A., Mataran L., Balsa A., Pascual-Salcedo D., Martin J., Genes. Immun., 1, 338-340 (2000).

4) Fernandez-Botran R., Expert. Opin. Investig. Drugs, 9, 497-514 (2000).

5) Paleolog E. M., Hunt M., Elliott M. J., Feldmann M., Maini R. N., Woody J. N., Arthritis. Rheum., 39, 1082-1091 (1996).

6) Gerritsen M. E., Kelley K. A., Ligon G., Perry C. A., Shen C. P., Szczepanski A., Carley W. W., Arthritis. Rheum., 36, 593-602 (1993).

7) Standiford T. J., Kunkel S. L., Rolfe M. W., Evanoff H. L., Allen R. M., Strieter R. M., Am. J. Respir. Cell. Mol. Biol., 6, 75-81 (1992).

8) Conlon K., Lloyd A., Chattopadhyay U., Lukacs N., Kunkel S., Schall T., Taub D., Morimoto C., Osborne J., Oppenheim J., Young H., Kelvin
D., Ortaldo J., Eur. J. Immunol., 25, $751-756$ (1995).

9) Nakajima Y., Sato K., Morita H., Torikai S., Hidano A., Nishioka K., Kashiwazaki S., J. Rheumatol., 19, 1643-1646 (1992).

10) Bucala R., Ritchlin C., Winchester R., Cerami A., J. Exp. Med., 173, 569-574 (1991).

11) Chu C. Q., Field M., Allamd S., Abney E., Feldmann M., Maini R. N., Br. J. Rheumatol., 31, 653-661 (1992).

12) Aigner T., Vornehm S. I., Belke J., von der Mark K., Kirchner T., Verh. Dtsch. Ges. Pathol., 80, 282-287 (1996).

13) Miller V. E., Rogers K., Muirden K. D., Rheumatol Int., 13, 77-82 (1993).

14) McGuire-Goldring M. B., Meats J. E., Wood D. D., Ihrie E. J., Ebsworth N. M., Russell R. G., Arthritis. Rheum., 27, 654-662 (1984).

15) Ollivierre F., Gubler U., Towle C. A., Laurencin C., Treadwell B. V., Biochem. Biophys. Res. Commun., 141, 904 -911 (1986).

16) Alsalameh S., Amin R. J., Kunisch E., Jasin H. E., Kinne R. W., J Rheumatol., 30, 1680-1690 (2003).

17) Dayer J. M., de Rochemonteix B., Burrus B., Demczuk S., Dinarello C. A., J. Clin. Invest., 77, 645-648 (1986).

18) Maimone D., Guazzi G. C., Annunziata P., J. Neurol. Sci., 146, 59-65 (1997).

19) Selmaj K., Raine C. S., Cannella B., Brosnan C. F., J. Clin. Invest., 87, 949-954 (1991)

20) Sharief M. K., Hentges R., N. Engl. J. Med., 325, $467-472$ (1991).

21) Spuler S., Yousry T., Scheller A., Voltz R., Holler E., Hartmann M., Wick M., Hohlfeld R., J. Neuroimmunol., 66, 57-64 (1996).

22) Nagai H., Takaoka Y., Mori H., Mastuura N., Inflamm. Res., 45, 293298 (1996)

23) Nagai H., Goto M., Kamada H., Boda K., Kitagaki K., Takaoka Y., Gen. Pharmacol., 30, 161-166 (1998).

24) Illei G. G., Lipsky P. E., Curr. Opin. Immunol., 12, $712-718$ (2000).

25) Andreakos E., Expert. Opin. Biol. Ther, 3, 435- 447 (2003).

26) Lorenz H. M., Expert. Opin. Investig. Drugs, 9, 1479-1490 (2000).

27) Gatto M. T., Tita B., Artico M., Saso L., Contraception, 65, 277-278 (2002).

28) Abouzid K. A., el-Abhar H. S., Arch. Pharm. Res., 26, 1-8 (2003).

29) Henke B. R., Aquino C. J., Birkemo L. S., Croom D. K., Dougherty R. W., Jr., Ervir G. N., Grizzle M. K., Hirst G. C., James M. K., Johnson M. F., Queen K. L., Sherrill R. G., Sugg E. E., Suh E. M., Szewczyk J. W., Unwalla R. J., Yingling J., Willson T. M., J. Med. Chem., 40, $2706-2725$ (1997).

30) Cockerill S., Stubberfield C., Stables J., Carter M., Guntrip S., Smith K., McKeown S., Shaw R., Topley P., Thomsen L., Affleck K., Jowett A., Haye D., Willson M., Woollard P., Spalding D., Bioorg. Med. Chem. Lett., 11, 1401-1405 (2001).

31) Bruneau P., Delvare C., Edwards M. P., McMillan R. M., J. Med. Chem., 34, 1028-1036 (1991). 